Article

\title{
Lived Religion among Montreal's Grey Nuns during the Vatican II Era: A Subject of Debate ${ }^{\dagger}$
}

\author{
Dominique Laperle
}

check for

updates

Citation: Laperle, Dominique. 2021. Lived Religion among Montreal's Grey Nuns during the Vatican II Era: A Subject of Debate. Religions 12: 226. https://doi.org/10.3390/rel12040226

Academic Editor: Salvador Ryan

Received: 16 January 2021

Accepted: 18 March 2021

Published: 24 March 2021

Publisher's Note: MDPI stays neutral with regard to jurisdictional claims in published maps and institutional affiliations.

Copyright: (C) 2021 by the author. Licensee MDPI, Basel, Switzerland. This article is an open access article distributed under the terms and conditions of the Creative Commons Attribution (CC BY) license (https:// creativecommons.org/licenses/by/ $4.0 /)$.
Department of humanities, Pensionnat du Saint-Nom-de-Marie, Montreal, QC H3V 2C5, Canada; dlaperle@psnm.qc.ca

+ All quotations have been translated by the author from French except those from the Providence Province and the St. Joseph Province which were already in English.

\begin{abstract}
This article deals with changes in the devotional practices of the Grey Nuns of Montreal in the context of the Second Vatican Council. This apostolic Congregation, active since the 18th century, has preserved the prayers and devotions instituted by its foundress, Marguerite d'Youville, in its daily religious practice. Under the effects of the decree Perfectæ caritatis and the motu proprio Ecclesiae Sanctx, the general chapters of the ad experimentum period became the theatre of exchanges and debates around this heritage. Between the desire to adapt and the fear of losing popular and spiritual traditions, these consecrated women testify to their ability to make choices, to make necessary changes, and to preserve a delicate balance between the past and the present in their lived religion.
\end{abstract}

Keywords: Vatican II; lived religion; devotions; piety; Grey Nuns; women religious; experience; Montreal

\section{Introduction}

The Second Vatican Council (1962-1965) is recognized as a defining moment in the history of the Catholic Church (Alberigo and Komonchak 1995-2006). In Canada, the Church's aggiornamento has been the subject of several studies (Routhier 2001; Schultenover 2008; Attridge et al. 2011; Gaillardetz and Clifford 2012) on the theme of the Council's reception (Routhier 1993, 2001, 2004, 2006). However, cultural changes, including a rapid process of secularization (Meunier 2011; Meunier and Wilkins-Laflamme 2011) diminished the impact of Vatican II. In the predominantly French-speaking Canadian province of Quebec, this process was accompanied by a rapid take-over of the traditional areas of intervention of the Church by the provincial government.

The "new Pentecost" of the Catholic Church hoped for by Pope John XXIII aroused the enthusiasm of many committed and avant-garde Christians but surprised many ordinary believers who felt perturbed by the numerous transformations, especially on the liturgical level, with, for example, the dropping of Latin and the questioning of traditional devotions. In the eyes of the most zealous reformers, the "People of God" could no longer rely on the old forms of piety if they wanted to deepen their faith. The faithful were encouraged to focus on the texts of the Bible and actively participate in the journey of this "pilgrim Church" through a more interior spirituality, less oriented towards different material and symbolic mediations. Although the Constitution Sacrosanctum Concilium devoted only one section to "pious exercises" (No. 13), with the Council, Catholicism hoped to impose a modernization of lived religion.

Disappointed, many believers thought that the saints had been made to disappear overnight (Orsi 1985, 1996, 2003, 2005, 2011). For some of them, devotional practices served as a means of intimate connection with the intermediaries (saints) of the sacred and as the foundation of individual and collective identity (Maldonado-Estrada 2019). Many of the faithful no longer recognized themselves in the new post-conciliar expressions. 
It was in this context that a flourishing of the concept of "popular religion" emerged in post-Vatican II studies. Researchers in the humanities felt the need to explain the settingaside, or even the abandonment, of some practices by the Church. The study of popular religion thus became a means of rationalizing and explaining the existence of devotions (Dahan 2015a, 2015b). This trend flourished rapidly in Quebec in the 1970s, and for more than a decade, numerous publications and symposia fueled reflection on the concept (Lacroix and Boglioni 1972; Boglioni and Lacroix 1981; Lacroix and Simard 1984; Lacroix and Grammond 1985; Laliberté 2009, 2010). However, this idea was also the subject of much criticism in Quebec (Dumont 1972; Savard 1972; Laperrière 1984; Dahan 2015b) and around the world (Orsi 1985, 1996; Hall 1997). Its users were accused of basing their reflections on a binary opposition between a primitive past and a rational present, as well as an opposition between, on the one hand, the institutionalized religion with its official religious practices, and on the other hand, the religion carried out with the practices developed by believers or more precisely the proper meaning that believers conferred on official practices. At issue were also the multiple meanings of the term "popular" and the difficulty in finding a consensual definition. Understandably, the problem had to be considered from a different perspective (Zemon Davis 1984; Vauchez [1975] 1994; Ryan 2003, 2006).

As an alternative, the concept of "lived religion" seemed to be more appropriate. Appearing at about the same time as the term "popular religion" in France (Desroches and LeBras 1970) and Quebec (Savard 1972, 1980a, 1980b), it did not enjoy the same fate. It is American researchers who have given it a second life since the 1980s (Orsi 1985, 1996, 2005; Hall 1997). This conceptualization brings forward the idea of the complexity and variety of religious experience that is constantly changing. It is the result of interactions (individual or collective) with the sacred through normative practices codified by an official institution, but also of influences within a society, in each socio-economic environment. This lived religion is embodied in the gestures, thoughts, beliefs, material, and spiritual expressions that the faithful construct, which basically give individual meaning to so-called official practices. Their discourse is therefore not always in perfect harmony with the official teachings of the Church. This deconstructs the image of the religious homogeneity of Catholicism in Quebec and Canada. Michael Gauvreau (2005) was one of the first to give a more heterogeneous portrait of the Church before the Quiet Revolution. As a result, Quebec researchers are now paying more attention to this heterogeneity (Gauvreau and Hubert 2006; Hubert 2007; Dahan 2015a, 2015b, 2017, 2018).

Surprisingly, this approach has rarely been used by researchers who are dedicated to the study of religious orders, specifically those of women (Smyth 2007; Bruno-Jofré et al. 2017). Lived religion implies the concept of experience that physically and mentally integrates and structures socio-cultural learnings that are embodied in the life of each person or of the group, over time. Even if all members of the same congregation adhere to a charism, practice common apostolic works and are subject to the Catholic Church, this belonging does not reveal everything about the experience of each nun, especially on the spiritual level. As an autonomous subject, a woman who decides to join a religious congregation carries personal devotional beliefs and practices, often inherited from her family, that will be superimposed on those taught at the novitiate (Laperle 2019b). Thus, even if the constitutions and rules of a congregation impose daily activities, a liturgical calendar, and specific devotions, each nun can freely supplement them with her own choices or modify them in her private life.

It is therefore understandable that the period of changes imposed by the Council on religious congregations through the decree Perfectæ caritatis and the motu proprio Ecclesiae sanctæ offers a unique framework for analyzing the subject of devotions. Can we perceive conflicting viewpoints on this subject among consecrated women during the conciliar process? Were certain practices challenged? Did new modes of expression emerge? These questions will guide our analysis of a particular congregation, the Sisters of Charity of Montreal, also known as the Grey Nuns. 
We hypothesize that the return to the roots of the charism of the foundation maintained many devotional practices imposed by Marguerite d'Youville but set aside those adopted by the Congregation under the influence of the ultramontane movement. The sisters experienced this period of constitutional overhaul and the return to their roots through the prism of a new freedom of expression; the question of devotions would be the subject of debates that would not be resolved without weakening community unity. This article proposes to examine this subject using the archives of the Grey Nuns of Montreal. Our work is based on three types of sources: the official documents of the Congregation (Constitutions, rules, circular letters); the documenting of consultations made during the ad experimentum period through the various canonical Provinces of the Congregation; and some interviews. The first sources identify the traditional practices historically inscribed by the foundress since the beginning. These official practices of the Grey Nuns involve objects, prayers, gestures, and postures that exemplify through their experimentation a spiritual meaning. The second sources provide access to the words and ideas of the sisters. We can grasp their ideas and conceptions in discussions, requested adaptations, hoped-for additions, or the combinations between the old and the new that were sometimes achieved. Finally, the General Superior of the Grey Nuns gave us the authorization to conduct interviews with sisters about their lived religion and devotions. Unfortunately, owing to the COVID19 crisis and the required sanitary controls, only two sisters volunteered, and the interviews were conducted by telephone. Through these sources, we trace the spirituality and the devotions of the Grey Sisters, from the pre-community decade to the adoption of the final constitutions in the early 1980s.

\section{The Object of Study}

The Congregation of the Sisters of Charity of the Montreal General Hospital, known as the Grey Nuns, was founded by Marguerite d'Youville Dufrost de la Jemmerais in 1737 for the purposes of healthcare, social services, and sometimes education (Ferland-Angers 1945; Mitchell 1993, 2000). In 1960, it had 1969 professed sisters and operated 98 institutions (hospitals, homes for the elderly, nursing schools, orphanages, residential schools, etc.) in six canonical Provinces in Canada and the United States, as well as missions in Canada's Far North and abroad, including in Brazil, Tunisia, and Nigeria. In addition, communities branched out from Montreal and developed in the dioceses of Saint-Hyacinthe (1840), Ottawa (1845), Quebec (1849), and Pembroke (1926) (ASGM, Statistical Institute 1967). ${ }^{1}$

The spirituality and charism of the Congregation is based on the lived experience of the foundress. At the age of 26, Marguerite $d^{\prime}$ Youville received a unique grace: the discovery that God is Father and Providence (Faillon 1852, p. 19). By contemplating how much God is Father, Marguerite understood how mankind is a brotherhood. She then felt the call to live a compassionate love and service towards the poor of all categories, whatever their conditions of life. This was the charism that Marguerite d'Youville conveyed to her community and was the heart of the spirituality and devotional practices of the congregation.

Devotional practices are one of the identifying markers of a religious congregation and a way of symbolically supporting apostolic actions with a specific pattern of behavior, which the community recognizes as carrying a positive meaning that will permeate the religious experience of each nun. For the most part, these practices are channeled through objects. These objects, around which is recognized a prodigious and extra human force, are used according to specific modalities and can intervene in human life or within the different frameworks of daily life. The devotions established by the foundress as early as 1737 were inspired by her personal choices, the influence of the French school of spirituality and those already practiced in the hospital before it was entrusted to the Grey Nuns. The first and most significant devotion, the cult of the Eternal Father, was central

1 While I am aware of the canonical differences between "sister," "nun," "community," "congregation," "order" and "institute," I will used them synonymously. 
to the spirituality of Marguerite d'Youville (Beaudet 1961; Mitchell 1993). In her eyes, this devotion was embodied in the spirit and action of the Institute. The sisters' sense of charity and compassion for the poor, the sick, and orphans was rooted in the projection of God's feelings towards humanity. She wanted the nuns to draw from this source the spirit and virtues of their vocation. Litanies to the Eternal Father were composed, at her request, by the Sulpician Pierre de Lavalinière and were recited in the community as early as 4 April 1770. This devotion was also intimately linked to the idea of abandonment and blind trust in divine Providence. She said, "Providence is admirable: it has incomprehensible springs for the relief of the members of Jesus Christ; it provides for everything; in it is my full confidence" (ASGM, Letter from Mother of Youville to Monsieur Henry, 24 September 1770). A chapel dedicated to the Eternal Father was built after the fire of 1765 and when the initial site of Old Montreal was abandoned and a new Motherhouse was built in 1871, further north, in the city center, a side altar and a painting were dedicated to the Eternal Father.

Devotion to the Holy Cross dates from the founding of the General Hospital by François Charon de La Barre in 1692 and the Hospital Brothers of the Cross and St. Joseph who administered the institution before the Grey Nuns (Ferland-Angers 1945). This devotion was practiced by meditating its mysteries every Friday and on the feasts of the Finding (3 May) and of the Exaltation of the Cross (14 September). The Hospital was placed under the special protection of the Holy Cross, and the chapel of the new Motherhouse would adopt the same devotion. Marguerite d'Youville would make it the second axis of the spirituality of the Grey Nuns. A relic of the True Cross was acquired in 1827. The archives of the Grey Nuns also mention the loan of another relic of the Cross by Bishop Bourget in 1844 (ASGM, Journal, 1, p.13). The feasts and community Masses were therefore "an opportunity to venerate the relic of the true Cross that was on display" (ASGM, Chronicles, 14 September 1956) because the fact of "solemnizing the exaltation of the Holy Cross as usual, is based on this tree of death, the vitality of [the] apostolate of the institute" (ASGM, Chronicles, 14 September 1959). It was not simply a matter of externally worshipping the relic but rather of meditating on the great mystery and the teachings left by the sufferings and death of Christ as suggested in the book Les Saintes Voies de la Croix (Boudon 1661), which Marguerite d'Youville particularly loved. The nuns symbolically transposed the components of the cross (width, height, etc.) to their own lives by comparing "their own crosses" to that of Christ. They were thus able to compare their path to an ideal of perfection marked by total oblation. In the Motherhouse of 1871, the high altar was dedicated to this devotion.

The consecrated life of the Grey Nuns also found an apostolic and spiritual foundation in the devotion to the Sacred Heart. Also present since the foundation of the hospital in the form of a dedicated chapel, it went hand in hand with the devotion to the Cross. A confraternity to which all the sisters belonged had existed since 1749. The Grey Nuns perpetuated its importance and dedicated the second side altar of the chapel of the Motherhouse of 1871. In the eyes of the foundress, this devotion is restorative. For Marguerite d'Youville, Christ appears to be "the only mediator" because she did not separate in her worship the Son from the Father, or from the gift of mutual love that underlies it, or from the love of Christ who accepted the Cross out of love for humanity. She therefore called on the sisters to come together and imitate this gift of love and to fully grasp the sufferings experienced on the Holy Cross, out of obedience to the Father. The Feast of the Sacred Heart was also of great importance for the Grey Nuns and they renewed, on several occasions throughout the year, their consecration to the Sacred Heart. "The formula [was always] recited, in common, in the chapel, between two hymns" (ASGM, Chronicles, 28 October 1956).

The devotions dedicated to the Virgin Mary and St. Joseph occupied a daily place in the spirituality of the Congregation. Two altars were dedicated to them in apsidioles of the transept of the chapel of the Motherhouse of 1871. The Marian cult took the form of several recitations and the chronicles regularly mention the calendar feasts dedicated to it under different names (Our Lady of the Seven Sorrows, Holy Name of Mary, Annunciation, Immaculate Conception) and for which different prayers were recited: "Saturday, 
September 8, Beautiful feast. Little Madonna lies surrounded by ferns in our community hall. Our postulants sing at the community Mass. [ ... ] At the end of the Adoration of the Blessed Sacrament, we recite together the act of consecration to the Holy Virgin, proper to the institute" (ASGM, Chronicles, 8 September 1956). Proportionately, St. Joseph did not occupy the same place, but he was never forgotten because of his role in the Holy Family. He is honored by a painting above the chapel's high altar and in the liturgical calendar: "Friday, March the 1st 1957, Singing at Mass for both the closing of the retreat and the opening of the month of St. Joseph. Mother Superior distributes us leaflets from the Mass of the new saint and that of St. Joseph the worker" (ASGM, Chronicles, 3 September 1957).

Thus, from the founding of the Congregation to the eve of the Council, the presentation of devotions in the Constitutions and the Rule do not change much. The Congregation's feasts are those of the Exaltation of the Cross and the Sacred Heart (ASGM, Constitutions 1962, no. 2). The practice of prayers and devotions were to fulfill the "primary end of the Institute which is the glory of God and the sanctification of its members [ . . ]. They will remember that "whoever wants to follow Jesus Christ must renounce himself and carry his cross". They will strive to print in their souls the living image of Jesus Christ crucified" (ASGM, Constitutions 1962, no. 1). To achieve these goals, the Grey Nuns will practice daily spiritual exercises:

Morning and evening prayers: angelus three times a day; the attendance at Holy Mass, the half-hour meditation, the morning and evening spiritual reading, the special and general examinations, the office of the Most Holy Virgin, the rosary, the visit to the Blessed Sacrament. All these exercises are done in common except the visit to the Blessed Sacrament and one of the spiritual readings. (ASGM, Constitutions, 1962, no. 108)

Communal prayer and daily mass were central to the congregation. They built a strong sense of solidarity among the sisters. The influence of the French School of spirituality and the choices of prayers made by Marguerite $\mathrm{d}^{\prime}$ Youville also gave a strong identity to these women religious who knew that hundreds of them were praying at the same time in all the convents (see the daily routine of prayer in Appendix A). This experience shaped their identity in the pre-Vatican II era. Finally, those who were unable to attend communal prayer because of their duties in hospitals or elsewhere knew that retired sisters would make up for their absence.

The Constitutions do not detail all the devotional practices of the Grey Nuns, and it is necessary to rely on other sources, including chronicles, to better understand the subtleties. The integration of devotional practices was done through a routinization learned by the novitiate on annual retreats and through the Church liturgy of the temporal and the sanctoral. Each day of the week was dedicated to a specific devotion. Thus, Sunday was dedicated to the Holy Trinity, Monday to the Eternal Father, Tuesday to a saint of choice or a prescription of the calendar, Wednesday to St. Joseph, Thursday to Mother d'Youville, Friday to the Holy Cross, and Saturday to the Virgin Mary. Other religious practices were rooted in the tradition of the community.

Thus, under the guidance of the Mistress of Novices, young sisters studied in depth the life of the foundress, and special attention was paid to her charism and the mission. They learned the three P's: Père, Providence, Pauvre (Father, Providence, Poor), which sum up the charism. Experiencing the charism of the Congregation and the foundress was also made possible through the observation and the imitation of older nuns during day-to-day apostolates. The way they cared for their patients or the poor, exemplified how a Grey Nun should act in the spirit of Marguerite $d^{\prime}$ Youville. It was then impossible to forget the particular emphasis that the foundress laid out for the order in the daily lived religion in which they were engaged. The reading of the Constitutions was also a daily obligation that deepened the understanding of the charism, the mission, and the spirituality. For Vowed Grey Nuns, a Spiritual Conference was held once a month and during the annual retreat. Finally, the circular letters of the Mother General always discussed important topics for all Grey Nuns, notably elements of devotions and charism related to the foundress. All of these 
approaches and documents helped the Grey Nuns to develop a better understanding of, and appreciation for, the charism and spirituality of Marguerite $\mathrm{d}^{\prime}$ Youville. It is necessary to discuss the foundress of the Grey Nuns in order to grasp the weight of devotion she was accorded in the pre-conciliar period.

As early as 1847, the Congregation wanted the Catholic Church to recognize Marguerite $\mathrm{d}^{\prime}$ Youville as a saint. The authorities of the Congregation added for all of the members further prayer obligations in the liturgical calendar in order to speed up the canonization process that remained too slow in their eyes. The Congregation was not alone in this regard in the 1950s. Many other American and Canadian congregations were waiting for Rome's approval of the virtues of their founder (Cummings 2020). In the late 1950s, although important milestones were reached, the ultimate consecration was delayed. The nuns offered Masses and prayers in honor of Marguerite d'Youville. From the feast of Sainte-Marguerite, to her birthday, to her death or the foundation of the institute, every effort was made to keep her memory alive and implore God to inspire the Vatican's decision makers. The Grey Nuns were anxiously awaiting the decision of the medical commission charged with investigating her miracles:

Prayers continue today to the Virgin Mary. Uninterrupted, groups follow one another in the chapel for the recitation of the rosary. We prayed so much that it seemed impossible that a telegram from Rome would not bring us the good news. But nothing-nothing! (ASGM, Chronicles, 16 March 1957)

In order to strengthen the fervor or "popularity," or to put it better, to enrich the holy capital of Marguerite d'Youville and that of the Congregation in the lived religion of the sisters and the faithful, its authorities multiplied the distribution of various objects of piety and of her relics. While medals, images, and statuettes had been mass-produced since the 19th century, relics were subject to more attention and control. The ceremony of the opening of her tomb on 5 July 1958 was paradoxically the occasion of an experience of faith reserved for a privileged group (the sisters and members of the clergy present), but also an opportunity to produce relics in large quantities. ${ }^{2}$

Relics are generally divided into three groups. The first-class relics are the most valuable items because they concern a portion of the saint's body. Second-class relics include clothing worn by the saint or an item he or she used. Finally, third-class relics are objects (images, medals, fabrics) that have been placed in contact with the body of the saint. Thus, on the occasion of the exhumation of the remains of the foundress, when the Archbishop of Montreal, Cardinal Paul-Emile Léger, removed the inner seals of purple ribbon, passing through the coffin, he handed them over to the Superior General, saying, "for relics, Mother" (ASGM, Chronicles, 5 July 1958). The bones are "touched with large pieces of white, red, and green silk [and] the cotton wool that formed the tree, enveloping the bones, will be used for relics: 3 large boxes! [Finally, on] Sunday, each sister received a Medal of Mother d'Youville that had touched the revered remains" (ASGM, Chronicles, 6 July 1958). These relics are part of the process of forming a collective identity for the sisters, but also for the people, because the writings that present her as the "strong woman of Canada" (Faillon 1852, p. VII) and the accessibility to these relics allow the dissemination of her devotion. The relics of the foundress weave and strengthen ties within the religious family of charity in all dioceses where the Grey Nuns are active. The decree of beatification by Pope John XXIII in May 1959 brought to a new moment a story that would not be completed until the 1990s but that allows us to understand the attention to and development of her cult throughout the period of this devotion.

2 "Each of the nuns in the Motherhouse finds an image and two medals at their lunch cover" (ASGM, Chronicles, 15 October 1956). Similar distributions are also observed in hospitals and places accessible to the general public. See (Laperle 2019b). 
The importance of relics was not new for the Grey Nuns, but many devotions were, in fact, added during the episcopate of Ignace Bourget (1840-1876). Bishop Bourget was a key player in the rise of papal devotions in Montreal. As a fervent ultramontane, he endorsed emotional and expressive popular religiosity and he modeled it on the example he had witnessed in Rome in the hope of a religious revival in French-speaking Canada (Hardy 1999, p. 28; Dahan 2018, p. 261). The Grey Nuns embraced the movement rapidly. They were chosen by Bishop Bourget to design a reliquary for the remains of Sainte Janvière, a Roman martyr. They also began to venerate relics of St. Amable, St. Roch, St. Anthony of Padua, St. Alphonsus Rodriguez, and St. Placidus, also a catacomb saint. According to tradition, St. Alphonsus was said to have healed three sisters in 1840, after their prayers for him. ${ }^{3}$ Until the General Chapter of 1940, the Grey Nuns dedicated an annual novena to St. Alphonsus, which was replaced by a Thanksgiving Mass and periods of exhibition of his relics. ${ }^{4}$ The acquisition of the relic of St. Placidus was possible through the financial contribution of a group of elderly women living in the Grey Nuns General Hospital in 1865 (Bradbury 1993, p. 161; Dahan 2018, p. 267). During the 19th century, numerous other relics brought by Sulpicians, friends of the Congregations, and donations were treasured. They were kept in a reliquary and exposed during special times. Finally, the Grey Nuns also acquired for the chapel of the new Motherhouse a chromolithography of the fourteen Stations of the Cross from France in 1882, also a devotion introduced by Bourget.

This overview makes it possible to understand the articulation of the main axes of the Grey Nuns spirituality and the nineteenth century's additions to their collective religious practices. As women and heirs of their foundress, they made it their duty to reproduce in all convents and missions the liturgical and sacramental cycles. The central devotions were jointly reproduced, and the Grey Nuns had an acute awareness of living these moments of community spirit in synchrony, despite the distance between communities (Laperle 2019b). What could vary were the patronage feasts of the local superiors, the chaplains, the bishops, or specific dedications in the dioceses or in the geographical areas served by the sisters.

In terms of lived religion, we also note the importance of ambulatory liturgies. Whether in convents or in places of pilgrimage, many ceremonies gave concrete importance to relics or objects of devotion that imposed a dynamic relationship between the person, the group, and the place by sacralizing the daily space beyond the chapel. The example of the Motherhouse is particularly illuminating. The 1871 building is divided between areas reserved for nuns and those reserved for the public. The procession of objects in the wings dedicated to orphans, the elderly, and the poor, aimed to have an impact on their lives. For nuns, employees and patients, the object that passed through could be seen and even touched; whether it was the processional cross, the Blessed Sacrament or a shrine and its relic, it could heal or convert. The Grey Nuns were convinced that sincere prayer could find, through the intercession of the devotional object, a path to charity and the love of Christ. Thus, a miracle, a healing or a conversion could materialize. The chronicles are full of these examples. Thus, on the Solemnity of the Feast of Corpus Christi, the chronicler mentions that the "procession of the Blessed Sacrament by the house ended by the announcement of the conversion of an old Protestant man, Deo Gratias! “(ASGM, Chronicles, 3 June 1956). In other cases, the procession of objects brought protection:

3 “On 6 November 1840, Sister Beaubien, General Superior, asked Father Thévenet, p.s.s. in Rome to send a small portrait and a relic to be exhibited in our chapel to the faithful who constantly come to make novenas in his honor" (AGGM, General Administration, G01, A, 4, a, 26). From 30 October 1842 , his feast is celebrated by the Grey Nuns.

4 We can see the shortness of this devotion throughout the two decades leading up to Vatican II: "After the adoration to the Blessed Sacrament, the relics are exhibited, but fewer people came to our chapel" (ASGM, Chronicles, 30 October 1956); "The relic of Saint Alphonse Rodriguez was not venerated today. His novena has been shortened" (ASGM, Chronicles, 30 October 1957). 
At 1:30 a.m., long procession through the house. Our Mother General carrying the statue of St. Joseph opens the parade followed by novice and professed postulants. We stop at the community, the St. Joseph's parlor, the novitiate, the novice parlor, the postulate, the seniorate and finally the chapel, reciting each time an Exultation of St. Joseph and a prayer in order to preserve the house from fire. [This is followed by the visit] of Sister Jean-Marie, Sister of Charity of Quebec, who comes to tell us with simplicity her miraculous healing in 1927 by the intercession of Mother d'Youville and her rescue from the fire of Villa SaintLouis by the intercession of Our Foundress and St. Joseph. (ASGM, Chronicles, 23 May 1956)

While the lived religion of the Grey Nuns is largely marked by the liturgical obligations of the calendar and the prescriptions of the official texts, several gestures also come from traditions that these women have given themselves over the decades. Thus, when a nun was dying and had been administered Extreme Unction, it was customary to light a candle and place it on the altar dedicated to Our Lady of the Seven Sorrows. Within the Congregation, this sign was immediately understood and "three invocations to St. Anthony are recited in addition to the prayer for the dying when the sister's state is at its worst" (ASGM, Chronicles, 13 June 1956). This tradition persisted at the dawn of the 1970s (ASGM, Chronicles, 16 February 1961).

The Grey Nuns were always looking to celebrate Masses and feasts with beauty. Because flowers had symbolic value with saints, the Grey Nuns used them to enhance both liturgical and community celebrations. Flowers were displayed on the altars and throughout the convents. The sisters also made artificial floral arrangements, liturgical clothing, and colored candles in the Motherhouse's workshops and in various convents. In their vision of lived religion, this was a requirement to celebrate and honor God. Grey Nuns were also famous for their wax handicraft of the baby Jesus. Their devotion to the Child Jesus influenced the representation and the appearance of the wax figure. His countenance, his posture, and the whiteness of the clothes are not insignificant, because this appearance "reminds of the gift of life, the Gift of the Son by the Father and communicates the virtues of charity through his frail person" (ASGM, Chronicles, 25 December 1961). The wax figurine of Jesus was therefore the object of pride and the chronicles of the Congregation attached great importance to it as well as to the establishment of the Nativity scene at the end of December. ${ }^{5}$

Our crèche has changed its décor this year. The almost century-old canvas painted by Mr. Painchaud has been scrapped and a dark blue curtain veils the altar of Our Lady of the Seven Sorrows. At the top-half-circle is fixed a large white star with rays of the same color, a little below, an angel, also all white, unrolls an inscription. Around the barn, we put frosted fir trees. It is simple and artistic. (ASGM, Chronicles, 25 December 1956)

From the beginning, the Foundress welcomed abandoned children into her hospital, and it became an important part of the apostolate of the Grey Nuns. In the 1950s and 1960s, many of these sisters worked with children in orphanages, hospitals, and schools. The Child Jesus was the Perfect Infant, and his image was instilled within each of the Grey Nuns' young patients. The Manger Scene was an important reminder of the devotion of Marguerite d'Youville to this figure. The Grey Nuns paid attention to the Christmas Nativity and were critical if it was not displayed correctly: "This year, the characters of the crèche are scattered in an artificial rock. Our attention is directed towards the pretty bambino that rests in the crib, at the foot of the statue of the Virgin Mary" (ASGM, Chronicles, 25 December 1957). However, when too many changes were made, critics erupted: "For the first time, the Nativity scene was set up on the gospel side, just below the statue of St. Joachim. This makes a grumpy sister say that the 'Child Jesus was born this year

5 ASGM, L082, Chronicles of the Motherhouse, 25 December 1961. 
at his grandfather's house'. No fir, no snow, but flowers and palm trees, neither ox nor donkey, little Jesus is orphaned" (ASGM, Chronicles, 25 December 1960). The following year, the situation was corrected: "Pretty angels, a Holy Family honored by shepherds and magi the whole [scene] is more graceful than last year. Mother Superior carried the little Jesus in procession, whom they laid down delicately" (ASGM, 25 December 1961).

The nuns did not all feel the same way about this devotion. The generation born between 1925 and 1945 saw it as a colorful tradition, a good stage setting for Christmas time, but merely a devotion. For other sisters, the attachment to the Jesus of the manger was clearly a way of sublimating the impossibility of having a child because of their vow of chastity. The affection and devotion expressed in a somewhat childish way towards the wax Jesus met some needs. The discourse on symbolic fertility through the total gift to the apostolate could satisfy for a time, but the limits of spiritual motherhood were quickly reached (D'Allaire 1984b; Laurin 2012).

This overview of the devotions practiced by the Grey Nuns in the pre-conciliar period shows that this group of consecrated women had integrated a spirituality that was largely the fruit of the model desired by the foundress, but also influenced by the ultramontane culture of the nineteenth century. The Grey Nuns perpetuated the central elements of the Constitutions and the Coutumier. ${ }^{6}$ The authorities of the Congregation ensured that the institutional culture, traditions, and behaviors were known by all the sisters in their different apostolic fields and houses. Young novices were trained and, through the daily repetition of prayers and recognized devotional practices, were integrated into the model of the Congregation. Even if we note throughout the 19th and 20th centuries some new features, these never destabilized the principal practices of the Congregation. It would be quite otherwise with the Second Vatican Council.

\section{Vatican II}

\subsection{Anticipating the Council's Directions}

Pope John XXIII's calls for an ecumenical and pastoral council on 25 January 1959 surprised the Church but left no trace in the archives of the Grey Nuns before 1962. They do not appear to have participated in Cardinal Léger's pre-conciliation consultation in 1961 (Laperle 2019a). The chronicles mention the "Council" on the 11 April 1962, when on the afternoon of that day, "two buses take professed and novice sisters to St. Joseph's Oratory for an hour of prayer for the Ecumenical Council" (ASGM, Chronicles, 11 April 1962). It is interesting to note that the first acts of these nuns in connection with Vatican II are part of the experience of lived religion. Thus, in addition to going on a pilgrimage to the shrine on Mount Royal, they began to fast a few days before the official opening of the Council and held $24 \mathrm{~h}$ of devotion before the Blessed Sacrament for the success of the event (ASGM, Chronicles, 10 October 1962). As consecrated women, the Grey Nuns thus performed personal and collective exercises that could communicate to the actors of the Council a spirit of faith that would allow them to produce positive decisions for the Church.

Throughout the sessions, the nuns put themselves in a state of reception of Vatican II thanks to information transmitted by radio, television, religious magazines, and secular newspapers (Routhier 1997, 2006; Laperle 2015). Although the calls for spiritual solidarity with the Council fathers gathered in Rome came from the diocesan authorities, the Grey Nuns demonstrated their ability to make choices by adapting demands and integrating them into their usual practices. Thus, for the opening of the fourth session of Vatican II, they exposed the Blessed Sacrament for this purpose for a whole day but then allowed themselves to "venerate the relic of the true Cross with their staff" (ASGM, Chronicles, 14 September 1965). Thus, between 5 December and 8 December 1965, at the time of the closing of the Council, Cardinal Léger's directives were closely followed, and votive Masses were celebrated after the exposition periods of the Blessed Sacrament. However, many nuns

6 It is the book explaining traditions and practices of the nuns. 
chose, out of their own initiative, to regularly light candles at the Virgin Mary's altar, so that "the Good Mother who has suffered so much [Our Lady of the Seven Sorrows] will share with us her courage and faith" (ASGM, Chronicles, 6 June 1965, 13 July 1965, 22 November 1965, 5 December 1965). They also invoked Marguerite d'Youville or the Eternal Father, the latter of whom can "distill into the minds of the sisters the same wisdom that led the bishops to make these choices" (ASGM, Chronicles, 19 August 1965). The chronicler of the Motherhouse recalls that it was difficult to agree on all the events and changes that lay ahead, but their beliefs and devotions, particularly in Divine Providence, clearly appeared as a means to curb fears and apprehensions and to put themselves in a position of reception, even if the aspirations and the horizon of expectation of the nuns did not necessarily go in the same direction.

\subsection{The Renewal of Religious Life}

The Constitution Sacrosanctum concilium on the Holy Liturgy was the first major text of Vatican II. Published in 1963, it established major liturgical transformations, although some changes, notably on the use of the vernacular, had existed since 1958. The physical changes associated with liturgical renewal, especially during Mass, now celebrated with the priest facing the congregation, were the most visible transformations. There was, however, a back-and-forth movement between old practices and new forms throughout the period from 1965 to 1970. If some of the traditional processions, and expositions of relics, continued within the Motherhouse, the adaptations made to the life of prayer shook up the community routine and the lived religion:

After the Adoration of the Blessed Sacrament, the litanies of St. Joseph are recited, which will be done every Wednesday in March, but there will be no procession! Many are dissatisfied because Vespers will now be recited privately. One finds it strange to give preference to private expression instead of the collective Divine office recommended by Vatican II. (ASGM, Chronicles, 1 March 1967)

The aggiornamento period testifies to the numerous experiments and cross fertilization of old and new practices performed by the Grey Nuns, but also changes imposed by diocesan priests. Two examples will suffice to shed light on this idea. Whereas the "Holy Relics" feast usually allowed the exhibition in the chapel of the Motherhouse of a dozen reliquaries, in 1967, the liturgists of the community exhibited only two and without special ceremony. The liturgists legitimized the change through the devotional movement towards the Eucharist, as desired by the Council (ASGM, Chronicles, 5 November 1967). In another case, during a Mass followed by the procession of the Holy Rosary, the canon of the Mass was read in French and aloud, which baffled the nuns, who responded spontaneously in Latin, before resuming in French (ASGM, Chronicles, 1 October 1967). The next day, the exercises of the Holy Rosary were simplified by eliminating the eucharistic blessing expected by the sisters (ASGM, Chronicles, 1 October 1967).

During this period, the Grey Nuns added, removed, translated, and sung instead of reciting psalms and internalized individually rather than chanted collectively elements of their liturgical and prayer life. In short, they adapted, but they sought above all to maintain the sense of the contemplative dimension of their religious life. Many embraced these new practices with great joy. This was particularly the case for the Liturgy of Hours, which did not really pose a problem for the sisters. Recognition of the richness of the new office made available to the nuns through the Prière $d u$ Temps Présent was unanimous (ASGM, G01, A, 4, 01, 14, General Administration). However, sensitivities and emotions were more vivid when traditional practices were questioned. It was implied when a chronicler evoked her concerns to the Virgin Mary, "Queen of Light, stay with us in the darkness of those times that seem to want to keep you away from us" (ASGM, Chronicles, 24 November 1966), it was her own disarray that was evoked in this period of difficult change. Let us recall here that at the end of the Second Vatican Council, religious communities saw an increase in the departures of professed sisters, the dramatic decline in recruitment and the questioning of certain apostolates. This disarray could sometimes turn into bitterness when 
certain devotions were ignored or discredited by outsiders, especially clerics not sensitive to the culture of the Grey Nuns. Thus, on the occasion of the Feast of the Holy Guardian Angels, a guest priest gave a lecture without mentioning it, but dwelt instead on the feast of Saint Theresa of the Child Jesus, ${ }^{7}$ recalling the meaning of sacrifice and the importance of saving souls (ASGM, Chronicles, 2 October 1969). The sisters had no problem with the little saint of Lisieux for whom they also had a statue in their chapel, but the feast of the Holy Angels was seen as a positive feast for them and they were hoping for a word or two about it. There was a lack of communication between the priest and the sisters in this change. To their view, this was not appropriate and did not respect the tradition usually experienced on this occasion.

Of course, we must be careful not to generalize the reactions of the sisters from the chronicles of the Motherhouse to all Grey Nuns of the various canonical Provinces. Chaplains of the Congregation had imposed, often without warning, their vision of lived religion in a post conciliar context, but age, ethnicity, level of education and type of apostolate could influence the perceptions of the Grey Nuns. Chroniclers sometimes presented their devotions as those of all members of the community, but it was very likely that sisters in authority prayed to Marguerite d'Youville to seek guidance, while novices turned to St. Francis-Xavier as they began their mission, at the same time that a sister of the seniorate ruminated about her disabilities by fixing her gaze on Christ on the Cross!

Beyond these reservations, these sources offer a striking picture of the effects of Sacrosanctum concilium on traditional prayer life. With the enactment of the Perfectae caritatis decree on religious life on 28 October 1965 and its application details in the Motu proprio Ecclesix sanctx, on 6 August 1966, religious communities entered the heart of the ad experimentum period, as they had been ordered to adapt their constitutions, their apostolates and their way of life to the "Signs of the Times." Marguerite d'Youville, the original charism of the order and its spiritual base would be the subject of substantive work. It is during this period that devotions would be scrutinized by new council requirements, contemporary sensibilities, and the experience of these consecrated women.

\section{The Question of Devotions in the Special General Chapter of 1967}

The establishment of a special general chapter ${ }^{8}$ following the promulgation of Perfectx caritatis and the motu proprio Ecclesix sanctæ initiated the process of modernizing the Constitutions, adapting the apostolates to the new secular world, and renovating religious life. Before arriving at the actual chapter exchanges, the generalate issued guidelines in September 1966 to allow the Grey Nuns to read the documents of the Second Vatican Council and to initiate consultations in all their convents. Comments on the situation and proposals for change or status quo were systematically supported by quotations from the Council texts according to a sheet model proposed by the General Administration. These forms were collected by canonical Provinces and sent to the Motherhouse with a general synthesis. This production, which has hundreds of pages, confirmed the substantive work on the corpus of the Council carried out by all the Grey Nuns and the process of reception of its teachings.

In terms of devotions and religious practices, the daily lives of the Grey Nuns were overloaded (see Appendix A). In a certain view, the Grey Nuns were apostolic sisters subject to the obligations of contemplative nuns. The rules' prescriptions structured the acts of piety through the practice of daily secular activities. This placed constant stress on the sisters who had to give up tasks in the middle of performing them in order to meet their obligations to recite their prayers in groups in the workplace or in the chapel. Even though older sisters of the seniorate would compensate for those who were unable to take time to pray, active sisters felt guilty about this. As sister Rita Stumpf recalled,

\footnotetext{
7 The feast of St Therese took place on the previous day (1 October).

8 A general chapter is an assembly of representatives (capitulants) from all the canonical provinces of the congregation. It takes place every five years. A general chapter is always the time for the renewal of the superior general and her council, the adoption of broad apostolic guidelines and changes to the Constitutions. Following Perfecte caritatis, the special general chapter happened in all male and female congregations across the world.
} 
"balance between prayer and apostolic action is easily obtained if prayer is understood in depth and the activities are truly apostolic in nature. Prayer is not an island in time unconnected to the rest of life. Its value is not measured by the clock, nor a multiplicity of exercises" (ASGM, General Chapter, 1967). This accumulation of prayers of all kinds bound the nuns to a routine that limited personal initiative. The nuns therefore expressed their desire to change this. As some sisters active in Alberta remarked,

The multiplicity of vocal prayers is not in the spirit of the Holy See. Since the external exercises of piety to be done in common should not be unnecessarily multiplied, too many vocal prayers interfere with prayer, and experience shows that the repetition of commonly recited vocal prayers does not promote true piety; may the Divine Office be the only common prayer. (ASGM, General Chapter, 1967)

Others point out that new nuns, especially those who had been involved in specialized Catholic action since their youth, were reluctant to repeat words that seemed meaningless to them. Michael Gauvreau underlines this idea when he mentioned the "unbridgeable chasm between two diametrically opposed religious mentalities as the key to the historical development of French-Canadian society" (Gauvreau 2005, p. 61). Numerous college students, intellectuals and clerics displayed a common allegiance to Emmanuel Mounier's personalist ideology. Personal creativity and spontaneity were key values for a new kind of spirituality. Old devotions were criticized in the same way. A sister of the Nicolet Province explained:

Devotions deserve an explanation adapted with contemporary words, for to evoke Jesus, Joseph, Mary or any saint must not lead us only to say, "My God, make me succeed in my apostolate", but rather "make me understand your Will and convert me for good to your love, so that I may be in your hands the flexible, generous and effective instrument of your work". A young sister told me, how her ideas change 'when I understand why I pray!' "So frankly, let us be less humdrum! Prayers and acts of piety are best done when recited alone. They are more in-depth and therefore better assimilated. (ASGM, General Chapter, 1967)

The ancient devotions that formed the spiritual identity of the Grey Nuns were not fundamentally questioned by most of the sisters, because they saw them as a legacy of the foundress. The process of canonization, which accelerated after 1959, offered the nuns the opportunity to measure Marguerite d'Youville's contribution to the construction of this common identity. The Second Vatican Council stressed the importance of returning to the roots of the founder's charism, and in this respect, the Grey Nuns had already taken steps forward. However, the choice of words, the ways of reciting, and the main themes developed around the Youvillian devotions by the French School of Spirituality were dated, according to some (ASGM, General Chapter, 1967). The length of the litany to the Eternal Father and its repetitiveness was highlighted. Sisters asked for an update of the ways of understanding and saying these prayers: "Many nuns yearn for a revival of devotion to the Eternal Father, a devotion that seems to be fading away more and more. It is proposed that the invocations be shortened in smaller meditation subjects to revive it" (SGM, General Chapter, 1967). Others mentioned that it would be better to distribute every day some excerpts from the aspirations of the Eternal Father and the litany of Divine Providence, so that they would be recited in full each week (ASGM, General Chapter, 1967).

The same thing can be seen with devotion to the Cross and to the Sacred Heart. A nun from the Nicolet Province wrote, relying on the Constitution Lumen gentium, that the Congregation

Is part of the body of Christ. In this body, the life of Christ spreads; we are united in a very mysterious but very real way to Christ suffering and glorified (LG, ch.1, art,7). We have always had this sublime wealth of love in the gift of Jesus' life for our sins. The Holy Cross reminds us of that. We observe and live it from the beginnings of the Congregation, through our devotion to the Sacred Heart and in our moments of intimacy with Him, in the chapel or at the presentation 
of Jesus-Host. I propose a continual and overabundant Thanksgiving towards Jesus, and a greater awareness of our sisters with the presence of Jesus crucified. This union with Christ is also linked to the love and liberality of a God as great, as powerful, as magnanimous as our good Eternal Father. Our original devotions fit perfectly into the renewal of the Council and it is good to remember it. (ASGM, General Chapter, 1967)

In a dolorist vision of the duty of the members of the community, Sister Jeanne Dugas stressed that devotion to the Cross could deepen at the same time as that of religious consecration in the light of the mystery of Christ's death and resurrection. "To be nailed to it. Duty like Jesus and with Jesus on the Cross, this is the ideal of the consecrated soul. We are like Christ saving the world through self-giving" (ASGM, General Chapter, 1967). At the other end of the spectrum, another sister, who was only identified by her age, concluded by pointing out, not without provocation, that she preferred a "Jesus as a friend who looks at us with affection in our daily work rather than a suffering Christ, looking elsewhere. As I am small, turned on the cross as he is, I may go unnoticed! "(ASGM, General Chapter, 1967). This irreverent remark illustrated for this sister the weight of a discourse on the sacrifice, far from daily experience, of an unattainable and inimitable Jesus in the absolute and the desire that her modest daily efforts be appreciated simply for what they were.

The opportunity, through this Council consultation, to express oneself freely was an important learning moment for these consecrated women. It showed that there were gaps within the Congregation around traditional ultramontane devotional practices. Above all, there was a tug-of-war between maintaining collective practices and respecting the pace and inclinations of individuals. A balance was clearly sought with lived experience, but not everything was to be swept away. Sister Patricia Baker from St. Vincent's Hospital in Toledo, Ohio illustrated this idea. She noted that Grey Nuns "historically manifested through prayer their solidarity with the other sisters.

"The Itinerarium expresses the wishes of the sisters for the protection of travelers during their journey. We must maintain the custom of praying the Itinerarium in common, for the sisters departing on a journey of considerable distance. We must also treasure the practices and exercises of devotion towards the Virgin Mary. We must continue the recitation of the Rosary as obligatory but said in private as we are now doing on an experimental basis as for the visit to the Blessed Sacrament". (ASGM, General Chapter, 1967)

Another nun from the Ville-Marie Province pointed out that devotion to the Blessed Virgin Mary was part of the tradition of the Church and of the Congregation. It was not something that could be turned away just as a fad. She pointed out that exchanges were sometimes the scene of mutual misunderstandings,

"Rather than prolonging sterile debates, would it not be important to point out to some of our sisters that the designations related to the Virgin are indications? It does not matter if I prefer Our-Lady-of-Joy to Our-Lady-of-the-Seven-Sorrows, after all, it is to Mary that we pray!" (ASGM, General Chapter, 1967)

The forms of prayer addressed to her also seemed to have provoked a variety of reactions. The regular practice of the rosary was one. Through the proposals, there was a tendency among young professed to appreciate this practice less and less. Many of them found the recitation monotonous. To their eyes, the time devoted to it was wasted. It had to be made optional, which was not the opinion of all,

"The rosary was not discussed by Perfectre caritatis, but it was encouraged by the text Christi Matri of Paul VI last September. The Virgin herself recommended it in Lourdes and Fatima. Just as the Rosary saved Christendom on several occasions, it is proposed that the rosary be recited together at the most appropriate time". (ASGM, General Chapter, 1967) 
An anonymous sister of the Motherhouse noted, "in the deleterious atmosphere of the current years, the harmful influence of individualistic tendencies." Some sisters had, according to her, "the shame or horror of our Holy Devotions." This illustrated "the greatness of sin in some." She argued that in order to "help them understand their immorality, we must in order to find in the devotion to the Child Jesus and that of Christ on the Cross, call them to look at the manger and the ordeal, the foundations and richness of the work of Blessed Marguerite" (ASGM, General Chapter, 1967). A sister working at the Rousselot Elder Care Center concluded, "St. Amable and St. Alphonsus were presented to me by the Mistress of novices. How can we protect our heritage if nobody takes time to explain these devotions in depth?" (ASGM, General Chapter, 1967).

Understandably, many nuns maintained the idea that knowledge and regular practice of devotions were necessary components of the Youvillian identity. The spiritual, even miraculous, effects of these gestures and prayers were essential aspects of their religious experience as well as discipline and suffering. Paradoxically, others saw the reforms launched by the Second Vatican Council as a necessary change, "The many devotional forms that had been developed in the preceding decades [were seen] as regressive and irrelevant expressions of an infantile faith no longer acceptable in a spiritually sophisticated community" (Orsi 1996, p. 32). However, the abandonment of numerous collective prayers broke, in many ways, the spiritual union between members of the congregation. The old daily routine ensured a collective conscience. The call for a more personal approach was seen by many retired sisters as a betrayal of the communal spirit. This was contested by a younger sister:

It is true that in the houses where our sisters are older, more communal prayers are perpetuated. The only commune prayer maintained throughout the congregation is vesper. We also pray for our dead sisters. Each time we receive the news of the death of one of our own, we gather for an evening of prayers and the next day for the funeral. Every year, we celebrate the Jubilees or other important feasts. Unity within the sisters are not only in vocal prayer anymore, but in a state of mind. Ultimately, our foundress left us this word on her will: "Make the most perfect union among you." (ASGM, General Chapter, 1971)

Less problematic was the Council's emphasis on the Eucharistic dimension. In all provinces, there were proposals to that effect. For example, the Alberta Provincial team was enthusiastic about promoting Mass as the center of the community's daily schedule. For them, the intensification, and the internalization of this "Divine Mystery in which the Verb (Word) is present in the Holy Bread and placed in a new way into the vision proposed by the foundress" (ASGM, General Chapter, 1967).

\section{Devotions in the Temporary Constitutions of 1967 and 1971 and the Final Constitutions of 1981}

The temporary Constitutions of 1967 illustrated the delicate balance achieved between tradition and change in the period of aggiornamento. Clearly, however, the Second Vatican Council's reforms transformed the cultural and social frames of meaning for the Grey Nuns. The new sensibilities are clearly expressed. In the former version of the Constitutions (the 1962 and 1966 versions), mention of devotions could be found in the early chapters. Instead, the new text of 1967 evoked the themes privileged by the Council: the importance of the Bible, the Holy Liturgy, and the Eucharist that were "the inexhaustible source of divine life where they find the strength to persevere" (ASGM, Constitutions, 1967, art. VI). The ancient constitutions mentioned devotions, prayers, and feasts related to the Virgin Mary, but they were intertwined in the general description of the exercises of piety (ASGM, Constitutions, 1966, art. 106-110). However, the daily experience of the Grey Nuns placed the Blessed Virgin Mary at the top of devotions with those of the Cross and the Eternal Father. In the 1967 temporary Constitutions, a complete separate article restored her pre-eminence by even granting her the title of "Mother of the Church," a designation that had been adopted by the Council Fathers. This illustrated the ability of these women to make choices and to 
favor formulations specific to their spiritual sensibilities. The love of the Cross is mentioned, but in the continuity of the love for God and the poor. The indications of the ultramontane Saints, relics, and feasts were removed, as was the list of obligatory prayers.

Although they were called upon to undergo further revisions in the following years, the 1967 Constitutions bore witness to a sincere reception of Vatican II. However, as Gilles Routhier pointed out, the reception process was a long-term affair (Routhier 2006) and the nuns themselves would modify this first version a few years later, in the light of their shared experiences, meetings held in 1969 and 1970, and changes brought on by the new social and ecclesial realities. Throughout the Ad experimentum period, the Congregation's authorities continued to collate these changes in different documents, notably by editing original historical sources. The return to the roots required the desire to imitate the original charisms of the first Grey Nuns and of their foundress. Henceforth, Grey Nuns became attentive to individual initiatives inspired by the Holy Spirit. During the 1960s and 1970s, the authorities of the congregation accepted and supported initiatives which differed from the usual apostolates, notably by sponsoring and welcoming immigrants or by opening a center for abused women. The broadening of the concept of poverty and the support of initiatives of projects by lay people confirmed the widening of the charism. Many lay people-men and women-also expressed during this period their desire to associate more officially with the Grey Nuns. This new partnership would be made official in 1983. In the same way, the sisters wanted to live an apostolic experience imbued with the presence of Jesus or a profound spirituality that impregnated daily work. As a sister close to the charismatic renewal movement attested, "inner life produces in those who sincerely experience supernatural radiance. How effective this radiance is! Because inner life engenders outer life, its results on souls are contagious, profound, and lasting" (ASGM, General Chapter, 1973).

In a survey conducted before the 1973 General Chapter, many sisters confirmed that the importance shifted from imposed collective vocal prayers to the requirement of taking the time to reconnect with God and to maintain a personal union with Him (ASGM, General Administration, March 1973). It was not so much a matter of always praying, but of intertwining prayer and action. Like the freeing of speech, the nun's body was liberated (Laurin 2012, p. 66) and allowed the expression of her spirituality and her devotions and confirmed how many Grey Nuns "now understand how central people's natural bodies are in the very practice and experience of religion" (McGuire 2008, p. 98). Thus, in the chapels of the convents, but also through the small fraternities that arose in anonymous urban apartments, sisters experienced new ways of living the liturgy with songs, non-traditional musical instruments such as the guitar or tambourine, but also postures of exaltation with arms crossed or gestures to the sky. Thus, many religious practices that linked bodies and emotion produced religious experiences (McGuire 2008).

Another nun who remained anonymous underlined how far she had come since 1967 and wanted the recent changes to be maintained. She noted,

As in the Second Vatican Council, there are the conservatives who preserved (sic) the past, who say that we are dropping everything, because there are fewer exercises in common than before, and that we abandonned certain devotions such as those of St. Roch and St. Amable. They are saddened that the little green curtains under the altar of Our Lady of Pity [Our Lady of the Seven Sorrows] are now still closed and that the shrine of the relics of St. Placidus is no longer visible. These are details in my opinion. Then there are the progressives. I am one of them and I entirely approve of what has been decided. (ASGM, General Chapter, 1973)

The period between 1967 and 1973 was the scene of exchanges and experiments, discoveries, and losses. It witnessed the decline of some symbolic and lived religion practices like kissing the floor upon rising in the morning as a sign of humility, the forsaking of vocal prayers like the Miserere and the Salve Regina dedicated to the Sulpicians, some collective rites (the Feast of Corpus Christi, the procession of St. Joseph's statue in the Motherhouse), 
and devotions to saints such as St. Roch or St. Placidus (ASGM, General Chapter, 1973). It did not please every sister, but most members accepted the changes linked to the Council documents. The new way to express the devotions integrated a finer understanding of lived ecclesiology. The desire to deepen the spirituality of Mother d'Youville was widespread. It was not simply a question of devoting a hagiographic cult to the foundress, but of grasping the peculiarity of her charism. Not everything was swept away in a radical fashion, but, as Robert Orsi pointed out, it was important to provide new ways of "expressing and experiencing the emotional and moral content underlying the meaning of the symbol" (Orsi 1985, p. 163). Theological studies were one way to do this.

Studies have always been favored in the community, but the post-Vatican II era saw an increase of sisters' enrollments in theology. Many reasons for this can be found in the decree Perfectx caritatis for renewal, but the Grey Nuns' archives also mention pope Paul VI's apostolic Exhortation Petrum et Paulum of February 1967 and the three-day congress of 6000 women religious in March 1968 in Montreal (Laperle 2020, pp. 107-38). The catechetical renewal and the collective reflection from the congress created a momentum. Sisters asked for a deepening of religious life and charism though theological studies. As one of the Congress organizers, responsible for the local intercommunity catechesis team, the Grey Nun Réjeanne Grand'Maison noted about the need for theological education,

Sisters ask for a formation, that can help us to redefine our Constitutions. With more knowledge, together, we can also update our spirituality and adapt our service for the poor. Through the light shed by Vatican II and this gathering, women religious are in the city for the common good. ${ }^{9}$ Through better education, God the Father will give us power and liberty to relieved poverty and giving meaning to all the people). (ASGM, Congrès des religieuses de Montréal, Au fil de notre histoire, 1968-1969, p. 20)

Many sisters embraced theology, either a few classes, or a bachelor's or master's degree, in different institutions, mostly at the University of Montreal, the Dominican Institute of Pastorale in Montreal, or the University of Ottawa. The goal of these studies was not teaching or nursing, but rather to accept the social, cultural, and ethical changes of the period, and to share their vision with the lay people with whom they worked. The study of theology shaped for many Grey Nuns a better understanding of their life as vowed women. However, it was not without effect on some traditional devotions or liturgical practices.

The experience of congregational life as vowed religious felt by these consecrated women took on a more individual tangent, but without seeing community events disappear, even though from the 1970s until the adoption of the final Constitutions of 1981, the obligations related to the liturgical calendar decreased. Traces of the maintenance, addition, or recall of traditional devotions and popular practices are gleaned from the chronicles of the Motherhouse. During this period, there were five mentions of the erection of the crèche, which implies that it is was maintained year after year. The chronicles, however, mentioned the discrepancies in what should be the expected representation of the Nativity. Thus, when the juniorists assumed in 1968 the construction of a modern Manger scene in the chapel, the chronicler spoke of "the modern which makes one regret the old," quoting a nun describing the "Holy Family abandoned in the remains of a flying saucer!" (ASGM, Chronicles, 23 December 1968). In 1971, when the Nativity scene was dismantled, the chronicle read, "Poor Mary, poor Joseph, and poor little Jesus. They were alone this year, without the magi or the shepherds. A lost barn ... in addition, the crèche is being removed today, the feast of Epiphany, and it is not even remembered" (ASGM, Chronicles, 6 January 1971). It appears, therefore, that the transformations that reframed the representation of the Joseph-Mary-Jesus family displeased several sisters. It seemed minimalist and offended the emotional relationship and the intimate connection that many had with the expected representation. The enthusiastic reaction of the chronicler about an all-Canadian Nativity

9 The title of the Congress in French was Les religieuses dans la cité. 
scene that mixed firs, rocks, shepherds, and magi in 1978 challenged the logic of a purely aesthetic and symbolic representation of the Holy Family, but it illustrated the complexity of the religious experience and its expression (ASGM, Chronicles, 21 December 1978).

The complexity of lived religion and the devotional practices were evident in a review of the spiritual vitality of the Congregation presented in 1973, by the General Superior, Georgette Leduc. She mentioned that it would be pretentious to believe that this dimension could be easily grasped or synthetized for 1500 women at the same time. The only way to "seize it is by measuring its fruits "(ASGM, Spiritual Life, 1973). The knowledge of this assessment came "from experience ... the personal experience gained by each Grey Nun in living her apostolic religious life over the past six years" (ASGM, Spiritual Life, 1973). The words chosen by the Superior were important. The old hierarchy now made way for a collaborative leadership marked by the ability to listen to each sister. The statement of sister Leduc allows us to capture, through the questioning and its results divided by age groups, apostolic work, spiritual life, and devotional practices. Thus, old popular uses such as the crèche or the recitation of the rosary were in decline, according to a comment made by the General Superior. Some very ancient customs were contested, such as the devotions to Divine Providence, to the Eternal Father and to the Sacred Heart. For these three devotions combined, only $23.7 \%$ of the nuns who had between 1 and 29 years of practice conceded a prayer activity directed specifically towards these devotions. This was half the percentage recorded for those who had between 30 and 49 years of religious life and one could imagine the reaction of the older nuns, of whom more than $75.2 \%$ continued to respect the devotions.

Devotion to the Holy Cross also brought some surprises. Beyond the feast to which the Grey Nuns collectively attached themselves for historical reasons, the majority no longer lived the Cross as a personal component of their prayer. One of the explanations was perhaps the shift from a dolorist spirituality of suffering on the Cross and the imitation of Jesus crucified to that of Christ, the Divine Verb that was meditated upon through his Word (Bible) and which one sought and found in the manifestation of love to the poor and the acceptance of the weight of daily challenges. Having said that, we should take care not to think of rejection but instead, of a shift of sensibilities. The symbolic importance of the Cross persisted and the distinctive materiality of the silver cross as a sign of their spiritual family was anchored in their daily lives. At the General Chapter of 1981, a project to replace the silver crosses with a humbler wooden symbol, in connection with the vow of poverty, would surface, the debates taking a profoundly emotional turn. The visceral attachment of several nuns to their profession cross desired as such by the foundress and the determination of some not to part with it would bring the generalate to retreat from this radical action. On the handing over of the new crosses to those who wished to accept them, the Provincial of Ville-Marie would opt for the discourse on the Cross as found in the texts of the Second Vatican Council:

Wear this cross and always wear it as a sign of your covenant with Christ. This devotion to the Cross, Mother d'Youville received it as a legacy of the Hospital Brothers of the Cross and St. Joseph (Brothers Charon) and passed it on to all generations of Grey Nuns as a community inheritance. We meditate on the central mystery of our faith that the Glorious Cross reminds us of this proof of liberation from the world and the immensity of Jesus' love. He loves us, and invites us to prove our love to him, in return, by accepting our daily crosses, on the narrow path of the Cross. (ASGM, Chronicles, 21 December 1981)

The case of devotion to the Virgin Mary also illustrated the gaps within the community and some changes in spiritual awareness. In the 1973 review, 37.3\% of sisters who had less than 15 years of vows dedicated spiritual exercises to her regularly, while $81.1 \%$ of those who had accumulated 30 or more years of consecrated life prayed to her outside the days of obligation. The 1970s were marked by the demands of women in civil society and within the Church. Within the institution, women, both religious and lay, performed a major portion of the tasks of administration, charity, and faith education, as well as 
forming the bulk of the contingent of people attending Mass (Dumont 1990a, 1990b, 2001). Therefore, it should not be surprising to read, in the documents of the General Chapter of 1977, the thinly veiled criticisms of Mary's titles, the tendency to speak above all of her submission and her recovery for clerical and moral purposes, "Mary Queen of the House, Mary-Queen-of-the-World, Our-Lady-of-the-Seven-Sorrows, 'The Immaculate One,' why not Mary, Woman-IN-the-World? She would certainly speak more to our novices and to the women of today if we were to deal with her humanity" (ASGM, General Chapter, 1977). On the contrary, other sisters argue, "we should not fall into 'the vulgarity of certain updates of the Mother of God. We must give back the Grey Nuns and Montreal to Mary through processions and the rosary'" (ASGM, General Chapter, 1981). Another nun asked for "new courses in Mariology to understand and ensure our fidelity to the devotion to Mary transmitted by our Blessed Foundress. I also think we must find artists who can convey a more modern image of the Virgin. Many sisters are no longer motivated by the old images" (ASGM, General Chapter, 1981). These few examples illustrate how the relationship with Mary was changing. While this "presence has been recognized and experienced [ ... ] in a wide variety of ways, including viewing icons, touching statues and relics, using rosary beads" (Engelke 2011, p. 213), new reasons for this devotion were expected.

Other devotions went through the period with less difficulty. Sister Rose-Alma Lemire remembers the maintenance of the presence of a lit candle on the altar dedicated to Our Lady of the Seven Sorrows for the sisters at the end of their lives. The mention of All Souls' Day reflects changes in the decade 1971-1981 but also its adaptation. It was no longer a feast of obligation but in honor of the dead, the sacristans of the Motherhouse adorned the Masses with gold ornaments. The chronicle thus allowed the group to maintain gestures, celebrations, and objects for a celebration that "evokes spiritual meanings and experiences" (McGuire 2008, p. 56). However, the possibility of making choices was also confirmed, "each sister, according to her devotion, makes visits with indulgences in favor of the dear deceased. The chapel does not empty and all altars, statues and even paintings can count on prayers" (ASGM, Chronicle, 1 November 1980).

The devotion dedicated to Marguerite d'Youville consolidated and took on a new dimension. The network of Youvillian Congregations encouraged, wherever they spread on different continents, devotion to the foundress. During the same time, the rise of feminist demands within the Church and society furthered a better understanding of the contribution of women to the Church. It favored the recognition of strong female models, which also made feminist historians say that women like Marguerite d'Youville were forerunners (Dumont-Johnson 1978). In addition, the traits of a rigorous administrator, businesswoman, and active agent in the development of a social work were noted by the Grey Nuns, but also within civil society. During the period, there was no decline of fervor for Mother d'Youville. A young sister mentioned that one does not "get tired of hearing about a woman who has done so much. [She adds] that, without necessarily praying to her, I ask her for advice" (ASGM, General Chapter, 1981), which is a way of saying the same thing! The development of a shrine dedicated to her from 1961 in her hometown of Varennes on the south shore of Montreal, the maintenance of ancient pilgrimages, the development of religious tourism and the strengthening of knowledge of its historical contribution, notably under the pen of the historian and archivist, Sister Estelle Mitchell (Mitchell 1993, 2000), meant that the figure of the foundress remained the subject of sustained attention. There was also the interest of people who had moved away from religious practice but who wished to interact directly with the future saint. This confirmed Meredith B. McGuire's statement that "People believed that they could channel divine power directly, without clerical mediation to where it was needed" (McGuire 2008, p. 35). This variety of modes of expression of the sacred and the profane around Marguerite d'Youville reflected the many possible experiences of the sacred at the heart of the Church, but also in its periphery. When the cause of canonization was reopened in November 1981, the Superior General explained in a circular letter its importance, "The sanctity of a mother seduces us, engages us, challenges us. Her daughters must therefore bear witness to their Mother's zeal, 
and therefore to be the continuations of her life of charity, her devotion to the Eternal Father and her faith in Providence" (ASGM, General Administration, circular no 2, 14 December 1981). The Superior's attachment to Marguerite d'Youville, who was finally canonized in 1990, found "her explanation in the place [she grants] in the definition of [her] own identity" (Derwich and Dompnier 2002, p. 7) and was received by all the Grey Nuns with enthusiasm, without debate, the foundress being the symbol of their unity and ultimate devotion as presented now as the universal mother of charity (ASGM, Chronicle, 3 May 1959).

\section{Conclusions}

The new Constitutions of 1981 formalized the importance imparted to community celebrations. In a spirit of fidelity, the Grey Nuns maintained in the official texts the original charism and spirituality. The process of the reception of the Second Vatican Council had just reached the end of a phase. With Vatican II, the renewal of religious life had allowed greater freedom in reciting ancient prayers and removing outdated repetitions and hymns, allowing the Congregation to adopt the Divine Office which united consecrated apostolic people with monks and nuns in common praise.

The Grey Nuns' historical attachment to their devotions and their foundress had its roots in the coherence of discourse and in the consequent development of apostolic works. Each nun, by agreeing to glorify God, His Son, the Virgin Mary, and the other saints through the total gift of her daily life, the regular practice of devotions, but also the regularity of her presence in the various rituals, could expect to live a mystical experience of union and solidarity with her sisters and the realm of the sacred. Through the repetition of the obligations prescribed by the rules, the Grey Nuns attached themselves to a chain of memory by which they were linked with the traditions of their Congregation. The Grey Nuns' popular practices involved the utilization and revering of objects such as the rosary and relics, as well as the expression of faith through postures and gestures. As Micheline D'Allaire said, "we can speak here of a superhuman project of a life that is both apostolic and monastic, charged with multiple experiences that built the meaning of the sacred" (D'Allaire 1984a). This was done at the expense of certain needs, dreams, health, and sometimes in conditions of intimate suffering that obedience and the desire to overcome stifled. The repetition and observation of what had always been enough to bring meaning to these different mysteries and hope in the Other World infused the necessary energy to continue.

Nevertheless, there were changes in the ways in which members of religious communities lived their religion. The way that Grey Nuns experienced prayers, the apostolates, and the devotions all changed. The quest for meaning required, from the late 1930s on, but especially in the 1950s, further explanations of the means of sanctification chosen by each congregation; a more acute understanding of patronal feasts, devotional gestures and associated prayers was demanded by the members. Sisters were trying to develop a new understanding of their faith. It is therefore with enthusiasm that the Grey Nuns put themselves in a state allowing them to receive the Council. Theological studies were favored in the community. These university degrees helped the Grey Nuns to shape their constitutions, but also brought new meanings to their charism and their devotions. It also gave them an adapted language that allowed them to interact with lay people in the social and medical fields in which they worked.

The ability of women to act in the Church to create change was demonstrated, but also reflected the effects of a complex process on their profound identity. This experience of women was one of conversion. They entered a process of transformation where they began to consider their value as autonomous and free individuals. As agents of their spiritual life, they made choices and created a new hybrid vision of the old and the new. In post-conciliar culture, Jesus, Mary, the Eternal Father, the Foundress, and the other saints were now perceived as inspiring companions who had lived through difficult choices.

Most of the ultramontane devotions from the Bishop Bourget era were put aside because they were not part of the personal history of Marguerite d'Youville. Also, it was no longer appropriate to focus on miraculous dimensions or on a logic of accumulating 
prayers to obtain something. Rather, it was a question of offering a deeper meaning to the mysteries associated with devotions. As Robert Orsi points out, if the reformation maintained popular devotions within Catholicism, they would now be explained in words (Orsi 1996). Thus, a new symbolic change was sought through the special General Chapters and the Ad experimentum period.

Through all their post-conciliar approaches, the Grey Nuns wanted to revisit the spiritual dimensions of their charism and their vocation to bear witness, through their daily actions, to the authenticity and uniqueness of Youvillian devotions. This was not done without debate, sometimes dividing the nuns. Nevertheless, it can be said that the decrease in the number of vocal prayers, the rise of a more personal and intimate spiritual life, especially with Christ and Marguerite d'Youville, and the maintenance of a number of collective festive moments in connection with the liturgical calendar demonstrated that these consecrated women remained faithful to the spirit of the foundation. It was this strong attachment to their commune identity that ultimately empowered them to build a new consensus.

Funding: This research received no external funding.

Institutional Review Board Statement: Not applicable.

Informed Consent Statement: Not applicable.

Data Availability Statement: Not applicable.

Acknowledgments: This project would not have been possible without the support of Mylène Laurendeau and Alcée Penet of the Archives des Soeurs Grises de Montréal. Many thanks to Sister Ghislaine Desjardins, Sister Rose-Alma Lemire, Sister Faye Wylie and Sister Elaine Baite for their input on the life of the Grey Nuns. I also deeply thank Michel Dahan, who enlightened me on several questions related to relics and the concept of lived religion and gave me particularly good advice during the writing of the preliminary versions of this paper. I am indebted to the anonymous reviewers, Michel Côté, o.p., and Magda Fahrni, and for the complete revision of this paper at different stages. Finally, I dedicate this text to Antonella Picillo, dear friend and colleague.

Conflicts of Interest: The author declares no conflict of interests.

\section{Appendix A}

PRAYERS AT THE GREY SISTERS IN 1960 (compilation made by sister Ghislaine Desjardins, s.g.m.)

- Veni Sanctae Spiritus (individual)

Oration (in common)

After the oration

- Sub tuum, O Jesus living in Mary (in common)

After Mass

- The Crux, Ave spes unique, Our Father, De profundis (in common)

After lunch

- Some verses from the Imitation of Jesus Christ (in common)

Before spiritual reading

- Invocations to Divine Providence (in common)

Before dinner

- special consideration, prayer to the Virgin (in common)

After dinner:

- Recitation of miserere, Salve Regina, Our Father, Ave Maria (in common)

The 1st Monday of the month:

- Profundis for those who died in the Institute (in common) 
In the afternoon:

- Aspirations to the Eternal Father (in common), Spiritual reading (individually).

After dinner:

- Office of the Name and Coronation of the Blessed Virgin, Rosary, Father (in common)

- Ave for our sisters on the road, invocation to St. Amable to protect us from fires. (in common); spiritual reading or prayers in their personal cell before sleep.

Note: Numerous prayers were added on special occasions and Feasts in the Roman Calendar.

\section{Archival Sources}

ASGM = Archives des Sœurs Grises de Montréal (Archives of the Grey Nuns of Montreal)

- Series G01, B: Administration générale, 1957-1982 [General Administration]

- Series G01, C23: Rapport de la Supérieure générale sur la vie spirituelle, 1973 [Spiritual Life 1973]

- Series G01, C28: Vingt-quatrième Chapitre général, 1967 [General Chapter, 1967]

- Series G01, C30: Vingt-cinquième Chapitre général, 1973 [General Chapter, 1973]

- Series G01, C32: Vingt-sixième Chapitre général, 1981 [General Chapter, 1981]

- Series L082: Chroniques de la Maison mère, 1956-1981 [Chronicle]

- Institut de statistiques des Sœurs grises, 1967 [Statistical Institute]

- Constitutions and Statutes of the Sisters of Charity of the General Hospital of Montreal "Grey Nuns", 1956, 1960, 1962, 1966, 1967, 1971, 1981 [Constitutions], Montreal, Grey Nuns of Montréal

\section{Interviews}

- Sister Ghislaine Desjardins, s.g.m., 7 September 2020

- Sister Rose-Alma Lemire, s.g.m., 12 August 2020

\section{References}

Alberigo, Giuseppe, and Joseph A. Komonchak, eds. 1995-2006. History of Vatican II, (6 Vol). Leuven and New York: Peeters/Orbis.

Attridge, Michael, Catherine E. Clifford, and Gilles Routhier, eds. 2011. Vatican II. Expériences Canadiennes/Canadian Experiences. Ottawa:

Les Presses de l'Université d'Ottawa/The University of Ottawa Press.

Beaudet, Gisèle. 1961. La dévotion au père éternel chez Mère d'Youville. Montreal: Université de Montréal.

Boglioni, Pierre, and Benoît Lacroix, eds. 1981. Les pèlerinages au Québec. Québec: Les Presses de l'Université Laval.

Boudon, Henri-Marie. 1661. Les saintes voyes de la croix. Ou il est traité de plusieurs peines interieures $\mathcal{E}$ exterieures, $\mathcal{E}$ des moyens d'en faire un bon usage chrétien. Par feu M. Henry-Marie Boudon, docteur en theologie. Paris: E. Michallet Éditeur \& Imprimeur.

Bradbury, Bettina. 1993. Working Families: Age, Gender, and Daily Survival in Industrializing Montreal. Toronto: McClelland \& Stewart.

Bruno-Jofré, Rosa, Heidi MacDonald, and Elizabeth M. Smyth. 2017. Vatican II and Beyond: The Changing Mission and Identity of Canadian Women Religious. Montreal and Kingston: McGill-Queen's University Press.

Cummings, Katherine S. 2020. A Saint of Our Own: How the Quest for a Holy Hero Helped Catholics Become American. Chapel Hill: North Carolina University Press.

D’Allaire, Micheline. 1984a. Le Coutumier des religieuses, codificateur de vie? In Religion Populaire, Religion de Clercs? Edited by Benoît Lacroix and Pietro Boglioni. Montreal: Institut québécois de recherche sur la culture, pp. 235-55.

D'Allaire, Micheline. 1984b. Vingt ans de Crise Chez Les Religieuses du Quebec: 1960-1980. Montreal: Bergeron.

Dahan, Michel. 2015a. Imported Devotions: Roman Catacomb Saints in Ultramontane Montreal. Master thesis, McGill University, Montreal, QC, Canada. Available online: https:/ / escholarship.mcgill.ca/concern/theses/mp48sg64x (accessed on 20 June 2020).

Dahan, Michel. 2015b. Religion Populaire: Un Concept Toujours Pertinent? unpublished paper.

Dahan, Michel. 2017. Saint Zotique de Montréal: Itinéraire d'une dévotion ultramontaine (1845-2005). Études d'histoire Religieuse 83: 43-60. [CrossRef]

Dahan, Michel. 2018. From Rome to Montreal: Importing Relics of Catacomb Saints Through Ultramontane Networks, $1820-1914$. Histoire Sociale/Social History 51: 255-77. [CrossRef]

Derwich, Marek, and Bernard Dompnier. 2002. Les religieux, les saints et les dévotions. Siècles 16: 3-10.

Desroches, Henri, and Gabriel LeBras. 1970. Religion légale et religion vécue. Archives de Sciences Sociales des Religions $29:$ 15-20.

Dumont, Fernand. 1972. À propos du concept de «religion populaire». In Les Religions Populaires. Edited by Benoît Lacroix and Pietro Boglioni. Quebec: Les Presses de l'Université Laval, pp. 23-31.

Dumont, Micheline. 1990a. Une perspective féministe dans l'histoire des congrégations de femmes. Études d'histoire Religieuse 57: 29-35. [CrossRef]

Dumont, Micheline. 1990b. Les charismes perdus. L'avenir des congrégations religieuses féminines en l'an 2000. Recherches Féministes 3: 73-111. [CrossRef]

Dumont, Micheline. 2001. L'histoire religieuse sans les femmes. Études d'histoire Religieuse 67: 197-208. [CrossRef] 
Dumont-Johnson, Micheline. 1978. Les communautés religieuses et la condition féminine. Recherches Sociographiques 19: 79-102. [CrossRef]

Engelke, Matthew. 2011. Material religion. In The Cambridge Companion to Religious Studies. Edited by Robert A. Orsi. Cambridge: Cambridge University Press, pp. 209-29. [CrossRef]

Faillon, Étienne-Michel. 1852. Vie de Madame d'Youville, Fondatrice des Sours de la Charité de Villemarie Dans l'île de Montréal, en Canada. Montreal: Sœurs de la Charité.

Ferland-Angers, Albertine. 1945. Mère d'Youville, vénérable Marguerite du Frost de La Jemmerais, veuve d'Youville, 1701-71, fondatrice des Sœurs de la charité de l'Hôpital-général de Montréal dites Sœurs grises. Montreal: Beauchemin.

Gaillardetz, Richard, and Catherine Clifford. 2012. Keys to the Council: Unlocking the Teaching of Vatican II. Collegeville: Liturgical Press.

Gauvreau, Michael. 2005. The Catholic Origins of Quebec's Quiet Revolution, 1931-1970. Montreal and Kingston: McGill-Queen's University Press.

Gauvreau, Michael, and Ollivier Hubert. 2006. The Churches and Social Order in Nineteenth and Twentieth Century Canada. Montreal and Kingston: McGill-Queen's University Press.

Hall, David D., ed. 1997. Lived Religion in America. Toward a History of Practice. Princeton: Princeton University Press.

Hardy, René. 1999. Contrôle social et mutation de la culture religieuse au Québec, 1830-1930. Montréal: Boréal.

Hubert, Ollivier. 2007. Sur l'histoire du quotidien et la religion. Études d'histoire Religieuse 73: 77-82. [CrossRef]

Lacroix, Benoît, and Pietro Boglioni. 1972. Les Religions Populaires. Quebec: Les Presses de l’Université Laval.

Lacroix, Benoît, and Madeleine Grammond. 1985. Religion Populaire au Québec. Quebec: Institut québécois de recherche sur la culture.

Lacroix, Benoît, and Jean Simard, eds. 1984. Religion Populaire, Religion de Clercs? Quebec: Institut québécois de recherche sur la culture.

Laliberté, Micheline. 2009. L'Émergence de l'intérêt pour la religion populaire et son histoire: Aux origines d'un débat (1960-1970). Rabaska: Revue d'ethnologie de l'Amérique Française 7: 7-26. [CrossRef]

Laliberté, Micheline. 2010. Définitions et approches diverses de la religion populaire. Rabaska: Revue d'ethnologie de l'Amérique Française 8: 7-18. [CrossRef]

Laperle, Dominique. 2015. Entre Concile et Révolution tranquille: Les religieuses au Québec, une fidélité créatrice. Montreal: Mediaspaul.

Laperle, Dominique. 2019a. La consultation des congrégations religieuses féminines dans l'archidiocèse de Montréal en 1961: Une étude de cas. In Le Concile Vatican II et le Monde des Religieux (Europe Occidentale et Amérique du Nord, 1950-1980). Edited by Christian Sorrel. Lyon: Laboratoire de Recherche Historique Rhônes-Alpes (LARHRA, UMR 5190), pp. 213-24.

Laperle, Dominique. 2019b. Le destin d'une sœur grise de Montréal dans la Prairie: Contribution d'une «vie» anonyme au débat sur l'approche biographique en histoire. Études d'histoire Religieuse 85: 39-58. [CrossRef]

Laperle, Dominique. 2020. Faire projet d'un héritage. La réception du concile Vatican II chez les religieuses de l'archidiocèse de Montréal (1961-1988). Quebec: Presses de l'Université Laval.

Laperrière, Guy. 1984. Religion populaire, religion de clercs? Du Québec à la France, 1972-82. In Religion Populaire, Religion de clercs? Edited by Benoît Lacroix and Pietro Boglioni. Quebec: Institut québécois de recherche sur la culture, pp. 19-51.

Laurin, Nicole. 2012. Le discours sur la chasteté dans les communautés religieuses de femmes au Québec de 1900 à 1970 . Edited by Jean-Philippe Warren. Montreal: VLB Éditeur, pp. 54-67.

Maldonado-Estrada, Alyssa. 2019. Catholic devotion in the Americas. Religion Compass 13: e122292. [CrossRef]

McGuire, Meredith G. 2008. Lived Religion: Faith and Practice in Everyday Life. Oxford: Oxford University Press.

Meunier, Éric-Martin. 2011. Mutations culturelles et transformations de la nation québécoise au tournant de la Révolution tranquille. Schweizerische Zeitschrift für Religions und Kulturgeschichte/Revue Suisse d'histoire Religieuse et Culturelle/Rivista Svizzeria di Storia Religiosa e Culturale 105: 365-75.

Meunier, Éric-Martin, and Stéphanie Wilkins-Laflamme. 2011. Sécularisation, catholicisme et transformation du régime de religiosité au Québec. Étude comparative avec le catholicisme au Canada (1968-2007). Recherches Sociographiques 52: 683-729. [CrossRef]

Mitchell, Estelle. 1993. The spiritual portrait of Saint Marguerite d'Youville 1701-1771. Montreal: Grey Nuns.

Mitchell, Estelle. 2000. Elle a beaucoup aimé: Vie de sainte Marguerite d'Youville, fondatrice des Soeurs de la Charité, Sœurs grises, $1701-1771$. Montreal: Méridien.

Orsi, Robert A. 1985. The Madonna of 115th Street: Faith and Community in Italian Harlem, 1880-1950. New Haven: Yale University Press.

Orsi, Robert A. 1996. Thank you, St. Jude: Women's Devotion to the Patron Saint of Hopeless Causes. New Haven: Yale University Press.

Orsi, Robert A. 2003. 'The Infant of Prague's Nightie': The Devotional Origins of Contemporary Catholic Memory. U.S. Catholic Historian 21: 1-18.

Orsi, Robert A. 2005. Between Heaven and Earth: The Religious Worlds People Make and the Scholars Who Study Them. New Haven: Princeton University Press.

Orsi, Robert. A., ed. 2011. The Cambridge Companion to Religious Studies. Cambridge: Cambridge University Press. [CrossRef]

Routhier, Gilles. 1993. La réception d'un concile. Paris: Cerf.

Routhier, Gilles. 1997. L'annonce et la préparation de Vatican II: Réception et horizon d'attente au Québec. Études d'histoire Religieuse 63: 25-44. [CrossRef]

Routhier, Gilles, ed. 2001. Vatican II au Canada: Enracinement et réception. Montreal: Fides.

Routhier, Gilles, ed. 2004. Réceptions de Vatican II. Le Concile au Risque de l'histoire et des Espaces Humains. Leuven: Peeters.

Routhier, Gilles. 2006. Vatican II. Herméneutique et réception. Montreal: Fides. 
Ryan, Salvador. 2003. The most contentious of terms': Towards a New Understanding of Late Medieval 'Popular Religion'. Irish Theological Quarterly 68: 281-90. [CrossRef]

Ryan, Salvador. 2006. The Most Traversed Bridge: A Reconsideration of Elite and Popular Religion in Late Medieval Ireland. In Popular and Elite Religion: Studies in Church History 42. Edited by Kate Cooper and Jeremy Gregory. Woodbridge: Boydell \& Brewer, pp. 120-29.

Savard, Pierre. 1972. L'historien et la religion populaire au Canada français. In Les Religions Populaires. Edited by Benoît Lacroix and Pietro Boglioni. Quebec: Les Presses de l’Université Laval, pp. 97-106.

Savard, Pierre. 1980a. Aspects du Catholicisme Canadien-Français au XIXe siècle. Montreal: Fides.

Savard, Pierre. 1980b. La dévotion à sainte Philomène. In Aspects du Catholicisme Canadien-Français au XIXe siècle. Edited by Pierre Savard. Montreal: Fides, pp. 173-96.

Schultenover, David G., ed. 2008. Vatican II. Did Anything Happen? New York: Continuum.

Smyth, Elizabeth M., ed. 2007. Changing Habits Women's Religious Orders in Canada. Ottawa: Novalis.

Vauchez, André. 1994. La spiritualité du Moyen Âge occidental. Paris: Seuil. First published 1975.

Zemon Davis, Natalie. 1984. De la religion populaire aux cultures religieuses. In Religion Populaire, Religion de Clercs? Edited by Benoît Lacroix and Jean Simard. Quebec: Institut québécois de recherche sur la culture, pp. 393-416. 